\title{
About the baby and the bathwater: assessing the European Platform against Poverty
}

Sebastiano Sabato and Bart Vanhercke

Working Paper 2014.09

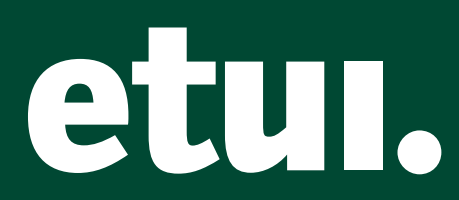




\section{About the baby and the bathwater: assessing the European Platform against Poverty}

Sebastiano Sabato and Bart Vanhercke 
Sebastiano Sabato is a researcher, both at the European Social Observatory (OSE) and at the Centre on Inequalities, Poverty, Social Exclusion and the City (OASeS) of the University of Antwerp. Bart Vanhercke is Director of the OSE and an associate member of the academic staff at the Centre for Sociological Research (CeSO), University of Leuven.

Brussels, 2014

๑ Publisher: ETUI aisbl, Brussels

All rights reserved

Print: ETUI Printshop, Brussels

D/2014/10.574/32

ISSN 1994-4446 (print version)

ISSN 1994-4454 (electronic version)

The ETUI is financially supported by the European Union. The European Union is not responsible for any use made of the information contained in this publication. 


\section{Contents}

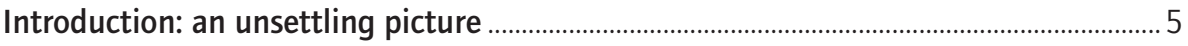

1. The social dimension of Europe 2020: coming of age? ……………………………......

2. A flagship against poverty: expectations and ambiguities .......................................10

2.1 A 'Platform' for horizontal cooperation: what's in a name? ................................... 10

2.2 A stakeholder involvement agenda ........................................................................ 13

3. The EPAP in action: hardly living up to expectations ............................................... 14

3.1 Horizontal integration: increased inter-DG cooperation but missing links with the European Semester ..................................................................................... 14

3.2 Policy coherence: an unfinished architecture ...................................................... 16

3.3 The EPAP Stakeholder dialogue: wider but increasingly shallow......................... 19

3.4 Vertical integration....................................................................................................... 21

4. The EPAP beyond the Mid-Term Review: three scenarios...............................................24

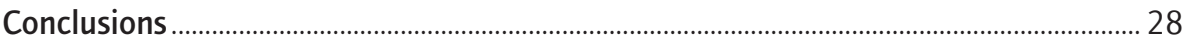

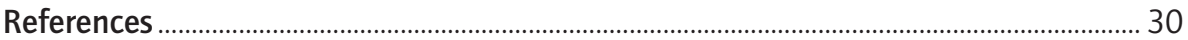




\section{Abstract}

This Working Paper provides a qualitative assessment of one of Europe 2020's flagship initiatives: the 'European Platform against Poverty and Social Exclusion' (EPAP). It begins with a description of the Platform's emergence and its place in the EU's social policy toolkit. It then critically assesses the (modest) strengths and (multiple) weaknesses of the Platform, four years into its implementation, by looking at four dimensions. First, the capacity of the EPAP to promote synergies between EU-level actors and processes (horizontal integration); secondly, its linkages with the other tools of 'Social Europe' (policy coherence); thirdly, EU and domestic stakeholder involvement; and fourthly, its capacity to link EU and national levels of governance (vertical integration). While the Platform has prompted some positive developments (e.g. broadened consultation, enhanced coordination within the Commission), its impact has been severely constrained. Crucially, the Platform is rather static and lacks the procedures to feed into the European Semester; in addition, it remains unclear how the EPAP is connected to the Social OMC and the Social Investment Package. Nevertheless, we argue that a transformed EPAP could provide strong added value for the EU's toolbox in the fight against poverty: rather than throwing out the baby with the bathwater, the mid-term review of the Europe 2020 Strategy should be used as a window of opportunity to revamp this tool. We propose three complementary scenarios for boosting, step by step, the effectiveness of the Platform: it could serve as a hub for discussing the social dimension of Europe 2020, as a bridge with the European Semester, and even as Social Europe's 'watchdog'.

\section{Keywords}

EPAP, Europe 2020, flagship, mid-term review, OMC, poverty, platform, SIP, stakeholders 


\section{Introduction: an unsettling picture}

The increasing social divergence between (Eurozone) member states that was triggered by the global financial and economic crisis has now reached a point at which it threatens to undermine the European Union itself (European Commission 2014c). High levels of youth unemployment and increasing divergence in rates of child poverty across the member states - ranging between 34\% in Romania and 10\% in Denmark in 2011 - reflect an investment deficit within a vicious circle of underperforming labour markets, lack of childcare provision, deficient education systems and inadequate transfer systems (Vandenbroucke et al. 2013).

In 2012, almost one in four Europeans (EU 27 data) - corresponding to around 122 million people - were at risk of poverty or social exclusion ${ }^{2}$. Although the overall trend has been upwards since the onset of the crisis, the impact again varies significantly across countries because the crisis has further exacerbated the differences in the national proportions of people faced with the risk of poverty or social exclusion. In 2008, the distance between the two extremes namely the Netherlands and Sweden with $14.9 \%$ of the population at risk and Bulgaria with $44.8 \%$ - amounted to 30 percentage points (pp). By 2012 the gap had expanded to $34.3 \mathrm{pp}$, between $15 \%$ in the Netherlands and $49.3 \%$ in Bulgaria (Frazer et al. 2014:12).

Perhaps most worryingly, an economist such as Thomas Piketty points to the 'arbitrary and unsustainable inequalities that radically undermine the meritocratic values on which democratic societies are based' (Piketty, 2014). The rise of the 'super managers' and the ensuing growth in income inequality is largely an Anglo-Saxon phenomenon but can be observed also to a lesser extent in Europe and Japan: income inequality 'is growing across and within member states, particularly in the South and periphery of the EU' (European Commission 2013k: 35-36). Data on the distribution of income in the EU show that, on average, in 2012 the top 20\% earned 5.1 times as much income as the bottom 20\% (European Commission 2014b: 9).

1. The authors would like to thank Chiara Agostini, Kenneth Armstrong, Denis Bouget, Hugh Frazer, José Goris, Renate Haupfleisch, Sian Jones, Peter Lelie, Antonino Sorrenti, Freek Spinnewijn, Herlinde Vanhooydonck, Jonathan Zeitlin and several DG EMPL officials for their critical feedback, and Valentina Recalcati for valuable research assistance. All interpretations and any errors that remain are the sole responsibility of the authors.

2. The 'at risk of poverty or social exclusion' indicator (AROPE) is composed of three subindicators: people at risk of poverty; people severely materially deprived; people living in households with very low work intensity. 
This unsettling picture stands in stark contrast to the EU's ambitious goal, agreed in March 2010 and framed within the 'Europe 2020 strategy', to turn the EU into 'a smart, sustainable and inclusive economy delivering high levels of employment, productivity and social cohesion' (European Commission 2010b: 1). What is more, Heads of State and Government committed themselves to lifting 20 million people out of the risk of poverty and social exclusion within a decade. Yet Frazer et al. (2014) illustrate quite clearly that, since 2010 when around 117 million persons were at risk of poverty, the figures have actually risen. The European Commission accordingly recognised in the Annexes to the Communication Taking stock of the Europe 2020 strategy ${ }^{3}$ that achievement of the Europe 2020 poverty target is beyond reach (European Commission 2014a: 25).

Against this backdrop, the purpose of this Working Paper is to provide a qualitative assessment of one of Europe 2020's so-called 'flagship initiatives', launched - in the form of the 'European Platform against Poverty and Social Exclusion' (EPAP) - to support the EU in delivering on its anti-poverty ambition. The paper is structured as follows. Section 1 provides a brief description of the main components of the Europe 2020 Strategy, focusing on its slowly maturing social dimension. Section 2 describes the emergence of the EPAP as well as its main features. Section 3 identifies the (modest) strengths and (multiple) weaknesses of the Platform, four years into its implementation. Section 4 proposes three scenarios for boosting, step by step, the effectiveness of the Platform. This paper concludes that, rather than throwing out the baby with the bathwater, the mid-term review of Europe 2020 should be used as a window of opportunity to reinforce delivery of the Platform.

3. This Communication has launched the mid-term review of the Europe 2020 Strategy. After a preliminary discussion at European Council meeting on March 21st and 22nd and public consultations during 2014, the Commission will advance proposals for reviewing the strategy early in 2015 . 


\section{The social dimension of Europe 2020: coming of age?}

At the time of its launching, Europe 2020 had a rather all-encompassing political agenda - resembling, to a certain extent, a return to the original Lisbon Strategy - that accorded considerable visibility and importance to employment and social inclusion. More concretely, Europe 2020 has been organised around three integrated (and supposedly mutually reinforcing) pillars: thematic coordination (in areas such as employment, education and social inclusion), macroeconomic surveillance, and fiscal surveillance under the Stability and Growth Pact. These three pillars of the Europe 2020 Strategy are currently organized through a 'European Semester'.

Thematic coordination focuses on structural reforms in the areas of employment, innovation (R\&D), climate/energy policies, education, and poverty reduction. It combines:

- EU priorities, e.g. Integrated Guideline 10 on 'promoting social inclusion and combating poverty'. While Guideline 10 focuses in particular on social inclusion, it also covers the areas of pensions and healthcare and is reminiscent, as such, of the main points in the common objectives of the 'Open method of coordination for Social Protection and Social Inclusion' (Social OMC).

- EU headline targets (with corresponding national targets). In the social sphere: to raise to $75 \%$ the employment rate for women and men aged 20-64 by 2020; to reduce school drop-out rates below $10 \%$; to increase to at least $40 \%$ the number of 30-34 year-olds completing third-level education; as well as the abovementioned target of lifting at least 20 million people out of the risk of poverty and social exclusion.

- EU flagship initiatives aimed at catalysing progress under each priority theme. The most relevant of these initiatives in the context of this Working paper are the 'Agenda for new skills and jobs' and the 'European Platform against poverty and social exclusion'.

While at first sight the employment and social issues in the Europe 2020 Strategy had some visibility, these were quickly subsumed under other - economic priorities. This was in line with the risks that were foreseeable if social issues were integrated into the EU main strategy (cf. Marlier and Natali 2010; Zeitlin 2010). Thus the Commission, in its first Annual Growth Survey (AGS), regarded pensions and healthcare as a burden on government budgets, with reforms being advocated in order to 'balance the books'. Equally importantly, this AGS of which economic crisis constituted a primary determinant factor - narrowed down social policy to the fight against poverty and social exclusion. 
A hardly unsurprising outcome of this stance, alongside the predominant focus of the AGS on economic issues, was that very few countries received Countryspecific Recommendations (CSRs) relating to poverty and social exclusion in 2011. Fiscal consolidation has been an overwhelming priority in the National Reform Programmes, while the attention paid to social issues has generally been marginal (Degryse 2012; Degryse et al. 2013; Derruine and Tiedemann 2011). More recent research (Agostini et al. 2013; Costamagna 2013; Jessoula et al. 2014; Vanhercke 2013) indicates, however, that the imbalance is being redressed to some extent and that the social dimension is slowly acquiring its substantive place in Europe 2020. Even if austerity policies have remained the overwhelming message of the European Semester (EAPN 2012, 2013b), 'tackling unemployment and the social consequences of the crisis' emerged as a priority in the 2012 Annual Growth Survey and has been confirmed in those issued for 2013 and 2014.

Recent AGS contain a more nuanced account of social issues, while an increasing number of CSRs focus on social objectives (notably with a view to poverty reduction): in 2013, recommendations under this heading were addressed to eleven countries (European Commission 2013b: Annex 1). In addition, CSRs are no longer accepted by the member states as 'set in stone': despite the heavy burden of the reverse qualified majority ${ }^{4}$, they are being successfully amended. Certainly, this 'socialization' of the European Semester (Barcevicius et al. 2014) is a slow evolution. Thus, the role of the Social Protection Committee (SPC) in Europe 2020 needs further clarification, as became clear in the discussions surrounding the 're-invigorated' Social OMC (Council of the EU 2011b) and, during the 2014 European Semester, the tense debate about who has the last word regarding the pensions CSRs (Zeitlin and Vanhercke 2014).

Nevertheless, it is remarkable that in an environment so strongly defined by the economic crisis, the Employment Committee (EMCO), the SPC, and the Directorate-General for Employment, Social Affairs and Inclusion (DG EMPL) of the European Commission have used the context of intensified 'mutual surveillance' throughout the year to strengthen their own analytical toolbox in the areas of employment, poverty, pensions and (to a lesser extent) healthcare and long-term care. The toolboxes in question include the Employment Performance Monitor, the more recent Social Protection Performance Monitor and the Joint Assessment Framework (Lelie and Vanhercke 2013). Furthermore, in order to strengthen the social dimension of the EMU, the Council decided to 1) complement the indicators used in the framework of the surveillance of macro-economic imbalances with a set of 'auxiliary social indicators' capturing the social implications of those imbalances; and 2) to develop a 'scoreboard of key employment and social indicators' to be used in the Joint Employment reports to allow for a better and earlier identification of employment and social challenges. Through this increased analytical capacity

4. Reverse qualified majority (RQM) voting implies that a recommendation or a proposal of the Commission is considered adopted in the Council unless a qualified majority of member states votes against it. 
the social affairs players increased their overall influence on the contents of the CSRs, albeit with a great deal of variation between the different social policy strands (Zeitlin and Vanhercke 2014).

All in all, it would seem that policy coordination in employment and social policy has been shown to be rather resilient. After four years of implementation of the European Semester, the employment and social actors involved have begun to formalize their positions and continue to do so in the preparation of the 2014 European Semester (Council of the EU 2013). Step by step, these actors have been devising ways of influencing decision-making processes in the new governance architecture, after having been faced with increasing 'problem pressures' and disappointing results of the first cycles of Europe 2020 (Agostini et al. 2013; Vanhercke 2013). The question to be asked here then is the following: what place has been reserved in this setup for the European Platform against Poverty and Social Exclusion? 


\section{A flagship against poverty: expectations and ambiguities}

\subsection{A 'Platform' for horizontal cooperation: what's in a name?}

In March 2010, the European Commission issued a proposal to create a European Platform against poverty and social exclusion 'to ensure economic, social and territorial cohesion' (European Commission 2010b). The proposal prompted immediate concern amongst the EU and domestic 'social affairs' players, for three main reasons:

- First, the proposal took quite by surprise many of the actors involved, including those in the European Commission's DG EMPL, creating the strong impression that this DG had not been in the loop when the initial proposal for the Europe 2020 flagship was tabled. This was indeed a top-down initiative that appeared not to have been properly thought through or to have entailed any consultation with stakeholders (Zeitlin 2010).

- Secondly, unlike the other six flagships announced by the Commission, 'there was no prior consideration given to what the EPAP would be and how it would relate to the existing EU coordination and cooperation in the social field' (Frazer et al. 2010: 22). A Commission official assumed that 'the drafting of the initial mandate of the European platform on poverty was not done by people who were extremely knowledgeable about the issue'. Other interviewees simply assumed the mandate had been tabled in a rush and had therefore not been given much thought.

- Thirdly, the precise formulation of the idea to launch the EPAP was ambiguous - and in fact rather incomprehensible - in that the European Commission (2010b: 19) proposed to 'transform the open method of coordination on social exclusion and social protection into a platform for cooperation, peer-review and exchange of good practice'. Since the notion of a 'Platform' could refer to many things (including a mere 'list of principles'), proponents of the Social OMC saw the formulation as a prelude to a further watering down - or even disappearance - of the existing toolkit (cf. Peña-Casas 2012: 175).

In sum, the institutional contours and specific aims of the Platform were unclear, including because '[T]he term 'platform' is meant to refer to a hub or host of initiatives oriented to bringing about social and territorial cohesion. The rhetoric around the Platform emphasizes especially innovation and 
experimentation in social policy' ${ }^{5}$ (Daly 2012: 276). This resulted in serious concerns especially regarding its relationship with the Social OMC. In the words of Philippe Pochet (2010:5): '[s]urprisingly, six months after the presentation of Agenda 2020, no one at this stage is able to define what is covered by the expression "platform against poverty", which is supposed to be one of the flagship initiatives of Agenda 2020. Is it a revamped OMC? A discussion forum? Or something else entirely?'

In the view of the SPC, the ambition of the Platform was to provide 'a wideranging and coherent programme for actions in the next decade in line with the new Strategy' (Council of the EU 2011a: 2). While the objectives of the EPAP remained rather vague, the Commission's follow-up Communication that was dedicated to this specific flagship initiative proposed a 'dynamic framework for action' through 64 'key initiatives', each of them associated with specific deadlines (European Commission 2010c: 3). As can be seen in Box 1 below, these initiatives can be grouped into six areas for action ${ }^{6}$ : (1) delivering action to fight poverty across the policy spectrum; (2) making EU funding deliver on the social inclusion and social cohesion objectives of Europe 2020; (3) developing an evidence-based approach to social innovation and reforms; (4) promoting a partnership approach and the social economy; (5) stepping up policy coordination among member states; and (6) building on the legacy of the European Year 2010 against poverty and social exclusion.

As can be seen from the examples of concrete initiatives in Box 1, the EPAP - as is the case for the other flagship initiatives - 'acts as an umbrella vehicle for more specific initiatives and [...] deploys a range of tools and instruments: e.g. legislation, non-binding recommendations, EU funds, policy coordination processes' (Armstrong 2012:289). Obviously, given the lack of legislative competences in this area, proposals for binding legislative acts are very limited in the EPAP (ibid.: 295). Interestingly however, some of the initiatives - such as the action on access to basic banking services, initiatives to combat the digital divide, and the promotion of energy efficiency measures targeting vulnerable consumers and marginalised communities - clearly go beyond the 'core business' of the Social OMC. Indeed, some of the actions proposed in the EPAP concern horizontal topics that are ultimately decided upon by otherthan-social actors and sometimes overlap with other Europe 2020 flagship initiatives.

5. The EPAP proposed to develop an evidence-based approach to social innovation and reforms, in particular through the promotion of 'social policy experimentation', small-scale projects designed to test policy innovations, initially concentrating on social assistance schemes. The European Commission has been financially supporting the development of social policy experimentation since 2009 through PROGRESS calls for proposals.

6. Different EU documents and the Commission website give somewhat different labels to the areas for action: some of them refer to five and others to six areas. In Box 1, we report 'areas for action' as listed in the Commission Staff Working Paper List of Key initiatives accompanying the Communication on EPAP (European Commission 2010a). 


\section{Box 1 The EPAP: examples of key initiatives}

1. Delivering action to fight poverty and exclusion across the policy spectrum, including:

- Present a Communication providing an in-depth assessment of the implementation of national active inclusion strategies, including minimum income schemes.

- Undertake an assessment of the efficiency and effectiveness of health expenditure; a Report on Health Inequalities will highlight the mutual links between poor health and poverty.

- Present a legislative initiative to ensure access to certain basic banking services.

- Present a Communication and propose a Council Recommendation on policies to combat early school leaving.

2. Making EU Funding deliver on the social inclusion and social cohesion objectives of Europe 2020, including:

- Propose for the new Cohesion Policy post-2013 a Common Strategic Framework that ensures coherence and complementarity between the Funds and identifies priorities to address poverty.

- Ensure that the objectives of poverty reduction social inclusion are duly reflected in 7th (2007-2013) Framework Programme on Research and Innovation and its successor.

- The use of micro-credits should be underpinned by local capacity-building initiatives and legislation changes in member states favouring their use by vulnerable communities.

3. Developing an evidence-based approach to social innovations and reforms, including:

- Launch a major initiative to promote social innovation: establish a 'high-level steering committee'; create a European research excellence network; launch a European research project; define common principles about designing, implementing and evaluating social experiments; ensure communication and awareness-raising; make use of existing financial instruments to support social innovation.

4. Promoting a partnership approach and the social economy, including

- Promote the sustainable involvement of civil society through the PROGRESS programme by providing support to key EU wide networks as well as through regular exchanges and partnerships between a wider set of stakeholders.

- Elaborate voluntary guidelines on stakeholders' involvement (and the participation of people experiencing poverty) in the definition and the implementation of policy actions and programmes, and promote their implementation at national, regional and local level.

- Propose a Social Business Initiative in order to support and accompany the development of socially innovative corporate projects within the single market.

5. Stepping up policy coordination between the member states, including:

- Assist and advise member states in view of the definition of national targets for the reduction of poverty and exclusion and of the most appropriate policies and reforms to meet the targets.

- The Commission will discuss with member states and other actors, how to best adapt the working methods of the Social Open Method of Coordination to the new governance of Europe 2020.

6. Building on the legacy of the European Year 2010 against poverty and social exclusion, including

- Strengthen the dialogue with the other institutions, in particular through regular exchanges on progress towards the poverty target.

- Transform the Annual Round Table on Poverty and Exclusion into a wider Annual Convention that brings together all relevant actors, takes stock of progress made towards the headline target, reviews the implementation of the activities under the Platform and provides suggestions for future action.

At least on paper, the EPAP as proposed in 2010 therefore presented an opportunity for mainstreaming at least some 'social priorities' into EU policies through coordination between several actors (e.g. between DG EMPL and other DGs). The Platform indeed 'seeks to address a gap that yawned wide and was never bridged during the Lisbon strategy, between social policy and other policy domains' (Daly 2012: 277). This is in line with the overall ambition of 
Europe 2020 to establish an integrated socio-economic framework for action and to mobilise for this purpose available EU instruments (including the single market, financial levers and external policy tools).

\subsection{A stakeholder involvement agenda}

From the outset, the European Commission expressed the ambition to involve a range of stakeholders in the EPAP's activities. At the EU level, the aim was to do this through 'an open, transparent and regular dialogue with stakeholders and civil society' (European Commission 2010a:11) and 'regular exchanges with stakeholders on key thematic priorities and in particular: active inclusion, child poverty, Roma inclusion, homelessness and housing exclusion, financial inclusion' (ibid.: 9). For this purpose, regular 'Stakeholder dialogue meetings' were to be organised7. The ambition was to reach out beyond the 'usual suspects' of social affairs players (say DG EMPL officials and EU-level NGOs networks), and to include representatives from other DGs within the Commission, EU-level social partners, representatives from international organisations, representatives from EU institutions as well as from EU agencies and national, regional and local authorities from the member states.

The action that really raised expectations was the Commission's announcement that it would 'elaborate voluntary guidelines on stakeholders' involvement in the definition and the implementation of policy actions and programmes to address poverty and exclusion, and will promote their implementation at national, regional and local level' (European Commission, 2010c: 17). Finally, and most visibly, the Commission planned to replace the Annual Round Table on Poverty and Exclusion (the key event of the Social OMC, jointly organised by the Presidency of the Council of the EU and the Commission since 2000) by an 'Annual Convention' of the EPAP. The stated aims of the new Convention go beyond that of the Round Table (see Box 1 above): the objectives are to gather a wide range of stakeholders and (a) take stock of progress made towards the headline target; (b) review the implementation of the activities announced under the Platform; and (c) provide suggestions for future actions.

The question then is: what happened to these ambitions once the EPAP was rolled out?

7. The detailed Minutes of the meetings held in 2011 and 2012 are available at http://ec.europa.eu/social/main.jsp?catId=961\&langId=en\&moreDocuments=yes 


\section{The EPAP in action: hardly living up to expectations}

Drawing on the description of the main EPAP actions in the previous section, we identify four main dimensions against which to assess its effectiveness: (a) horizontal integration: the capacity of the EPAP to promote synergies and coherence between EU-level actors and processes; b) policy coherence: the ability to promote a coherent anti-poverty strategy for action and integration with the other tools of 'Social Europe'; c) stakeholder involvement, both at the EU and national levels; and d) vertical integration: the EPAP's capacity to link EU and national levels of governance. We draw on primary sources (e.g. Minutes of meetings, official documents), the limited academic literature which refers to the EPAP, as well as some ten expert interviews conducted by the authors between the summer of 2012 and the spring of 2014.

\subsection{Horizontal integration: increased inter-DG cooperation but missing links with the European Semester}

The previous section highlighted that the EPAP includes some initiatives in areas that fall outside the immediate remit of DG EMPL. Evidence from the first years of implementation shows that, as a result of this, a more structured intrainstitutional dialogue has indeed developed. This happened more particularly through an 'Inter-Service Group' which has been meeting three/four times a year since 2011 and that brought together a critical mass of European Commission officials working on social inclusion in some twenty DGs. It should be noted that intra-institutional cooperation on social issues among European Commission DGs is not a new phenomenon: a 'permanent interservice group for mainstreaming social inclusion and social protection' was already in place before the launch of the EPAP (European Commission 2008: 6). However, several of our interviewees were of the view that the pre-existing inter-DG dialogue has been boosted by the setting up of the Platform and, more particularly, by the need to identify actions across a wide range of policy areas.

In the words of one EC official, the EPAP:

'Was a way [...] to get involved in other agendas that are relevant to fight poverty: education, migration, etc. And we managed to have this involvement of other services in the Platform. There was quite a lot of enthusiasm: the contributions of the other services delivered a quite impressive list of 
actions. [...] We needed to have an overview of what was going on and to mobilise this critical mass to be relevant in the 2020 processes.'

The meetings of the Inter-Service Group are situated at the operational level in that they involve line officials working on specific files. The purpose of the meetings is to exchange information, discuss and coordinate actions amongst different DGs. These include the Directorate-General for Justice (JUST), Home Affairs (HOME), Energy (ENER), Communications Networks, Content and Technology (CNECT), Development and Cooperation (DEVCO), Economic and Financial Affairs (ECFIN), Education and Culture (EAC), Health and Consumer Affairs (SANCO), Research and Innovation (RTD), Internal Market and Services (MARKT), Regional policy (REGIO) and the Commission's Joint Research Centre (JRC). This inter-service group has indeed taken action on some of the horizontal initiatives flagged by the EPAP. The latter includes the Proposal for a Directive in 2013 concerning, inter alia, access to a basic payment account (European Commission 2013h), measures to improve the quality of the legal structures relating to foundations, mutual societies and cooperatives; and the recent agreement on the more prominent use of environmental and social considerations in public procurement and concession contracts (European Parliament 2014).

Putting together initiatives related to the fight against poverty and social exclusion (including those implemented by other DGs), and discussing/ coordinating their implementation through the inter-service group, would seem to represent an opportunity for mainstreaming anti-poverty (and social) objectives into EU actions. This said, it is difficult to assess to what extent DG EMPL has really been able to 'gain ground' vis-à-vis other DGs in the Commission through this new coordination forum. Agostini et al. (2013: 58) raised doubts about whether sufficient staff and resources have been devoted to EPAP with a view to effectively managing such a potentially powerful steering instrument.

Perhaps this lack of resources explains why the EPAP's capacity to influence the broader EU policy process in the European Semester has been, to put it mildly, limited. Note that the institutional mechanisms that could have facilitated the 'feeding in' of EPAP actions and events into the overarching process (e.g. in the elaboration of the AGS, CSRs, National Reform Programmes) have been missing from the very beginning. Thus, the European Semester is mentioned only once in the Communication on the EPAP (European Commission 2010c), while the Platform is not involved in preparation of either the Annual Growth Survey or the Country Specific Recommendations. What is more, in spite of pressing and recurrent requests from European social NGOs (cf. Social Platform 2013; European Commission 2013c), the set-up of formal procedures that would link the EPAP's stakeholder dialogue meetings and the Annual Convention to the main moments of the European Semester is not on the agenda (see the scenarios elaborated in section 4 below). As a result, Commission officials involved in EPAP events are the only vehicle through which the latter's inputs may feed into the European Semester (cf. European Commission 2013c: 4). 


\subsection{Policy coherence: an unfinished architecture}

The Platform's formal ambition is to provide a coherent action programme designed to achieve the Europe 2020 poverty target. By systematically mapping ongoing actions in the area of poverty and regularly proposing a new agenda for action, the EPAP indeed has the potential to contribute to identifying priorities on which to concentrate efforts. Looking at the implementation of the EPAP, however, the practice of this mapping activity seems somewhat problematic. First, when launched in late 2010, the EPAP included 64 initiatives to be undertaken in the following years; most of these were already planned before the launch of the Platform and, as shown above, their choice has been almost exclusively the result of interactions among Commission DGs, with limited input from stakeholders. This fact, coupled with scarce communication about activities in the EC Inter-Service Group, has significantly weakened stakeholder ownership of the Platform, which is increasingly seen as a 'shopping list' of the various Commission DGs. Secondly, three years after the launch of the EPAP, in July 2013, the Commission explained that 23 of these initiatives had been completed (European Commission 2013e) and 41 were still ongoing (European Commission 2013f ${ }^{8}$. However, no new initiatives have been proposed since 2010, nor it is clear through which procedure such initiatives could be added.

This calls into question the EPAP's declared ambition to be a 'dynamic' framework for action (European Commission 2010c: 3). The absence of a broad strategic approach and the rather static character of the Platform come as no surprise, in view of its weak integration with - and unclear relation to - preexisting instruments (notably the Social OMC) as well as newly developed EU initiatives (especially the Social Investment Package). It should be noted that one of the initiatives foreseen by the EPAP concerned the adaptation of the working methods of the Social OMC to the new governance of Europe 2020. Supplying more detail on this point, the EPAP Communication announced indeed that:

'Based on the experience of the first European Semester of Europe 2020, the Commission will discuss with Member States and other institutional and non-institutional actors, how to best adapt the working methods of the Social Open Method of Coordination to the new governance of Europe 2020. The Commission will present a report before the end of 2011 summarising the orientations emerged and the follow-up it will give to it' (European Commission 2010c: 18).

However, the SPC (read: the member states) took the lead in the process of reforming the Social $\mathrm{OMC}^{9}$. Still, the questions regarding the exact relationship

8. Some of the 'ongoing initiatives' (such as the organisation of stakeholder dialogue meetings) are recurrent initiatives, while other initiatives have been completed in the meanwhile. In Annex 3 of the recent Communication Taking stock of the Europe 2020 strategy, the European Commission states that 'Delivery of the initiative is happening at a fast pace. The Commission has delivered approximately two thirds of the 64 actions' (European Commission 2014a: 35, emphasis in the original).

9. Quoting from the SPC report on the social dimension of the Europe 2020 strategy, 'The SPC will provide its input on how to ensure coherence between the objectives and the 
between the OMC and the EPAP were at the heart of the issues debated by the 'SPC Ad Hoc Group' that prepared the SPC's Opinion on the future of the Social OMC. Member states in the Ad Hoc Group were divided on the issue and concluded that:

'While in the opinion of a few MS the EPAP is broader as regards the instruments it draws on (the ESF, for example) and aims namely at mainstreaming social inclusion objectives in all EU policies, the Social OMC from the viewpoint of other MS is broader in its temporal, contextual and its substantive reach, as it also covers pensions and health care and long-term care from a social protection point of view' (SPC 2011a: 2).

The Employment, Social Policy, Health and Consumer Affairs (EPSCO) Council document endorsing the Ad Hoc Group Opinion remains equally vague when it asks that EPAP initiatives and the Social OMC should be 'mutually reinforcing' (Council of the European Union 2011b: 6). Thus, the relationship between the two processes and the practical arrangements for linking them remain unclear, even after the OMC's 'reinvigoration' in 2011, and such in spite of regular calls by EU institutions and stakeholders alike to clarify this relationship (CoR 2011; EESC 2011; EAPN 2011a and b). Rather telling is that, notwithstanding the clear interest towards EPAP expressed by the SPC in its work programme for 2011 (cf. Council of the EU 2011c), the Platform is not even mentioned in the 2012 and 2013 annual reports of the Social Protection Committee (cf. European Commission 2013i, 2014f).

The relationship between the EPAP and the recently introduced 'Social Investment Package' (SIP) equally raises some questions. Indeed, it would seem that the Commission envisages coordinating the EU's 'soft approach' to social policy through the SIP, which was launched in February 2013 (European Commission 2013a). The SIP sets out a European-level policy framework that addresses a wide range of social policies and has the ambition to match the European Commission's earlier encompassing 'Social Agendas' and to provide concrete guidance for the reform of member states' social protection systems ${ }^{10}$.

working-methods of the Social OMC and the new context of the Europe 2020 Strategy and its governance, on the basis of the experience of the first European Semester of Europe 2020' (SPC 2011b: 8). Quite clearly, if compared with the wording of the EPAP initiative mentioned above, this sentence completely 'reverses' the respective roles of the SPC and of the EC in the reform of the Social OMC.

10. While there is some hope that the Social Investment Package can create some room for manoeuvre and tangible support for member states that opt for a social investment strategy, some doubts have been raised on its capacity to represent a fully-fledged EU anti-poverty strategy (cf. EAPN 2013a). Indeed, as recognised by the European Commission, social investment is only one of the functions which should be performed by welfare systems, the other two being social protection and the stabilization of the economy (European Commission 2013a: 3). As pointed out by Vandenbroucke with Vanhercke (2014: 48), complementarity between social investment and social protection should be assured and 'it would be naïve to deny tensions between principles of social protection and principles of social investment and the emphasis on activation that is associated with it'. 
According to the EC Communication on the SIP (European Commission 2013a) and to the policy roadmap for its implementation (European Commission 2013g; 2014e), actions will be undertaken along three axes: 1) 'Strengthening the social investment approach through the European Semester', 2) 'Making the best use of EU funds to support social investment', 3) 'Streamlining governance and reporting'. Compared to the EPAP, in the documents related to the SIP the ambition to create linkages between the package and other EU processes (notably, the European Semester, the Social OMC and, more in general, SPC activities) is made more explicit. Indeed, according to the SIP policy roadmap (European Commission 2014e: 2),

'the Commission supports social policy reforms as set out in the Social Investment Package (SIP) through the follow-up to the 2013 Semester, through all stages of the 2014 and subsequent Semesters, and through dialogue with member states in the Social Protection Committee about the trends to watch pinpointed by the Social Protection Performance Monitor $(\mathrm{SPPM})^{\prime 11}$.

A closer look at initiatives envisaged in the SIP reveals a certain overlap between the former and some of the themes characterising the EPAP: these include attention to specific target groups such as children, Roma, homeless; active ageing; the emphasis on social innovation; and the use of EU Funds. And yet, the Platform is not referred to in the Communication on the SIP, with the important exception of the intention to continue the dialogue with all relevant stakeholders in the context of the Annual Convention of the Platform. (European Commission 2013a: 23) ${ }^{12}$

Consequently, it is not clear whether the SIP and the EPAP should be considered as complementing each other, or rather as parallel processes; or is the SIP meant to replace the Platform? A recent Commission publication refers to the EPAP as a 'key partner in the implementation of the social investment approach to poverty and social exclusion' (European Commission 2013j: 55). The same publication reduces the 'dual purpose' of the Annual Convention to (a) providing visibility and political weight (including through the presence of the European Council and Commission Presidents) to the social investment approach; and (b) building a supportive and active constituency around it (European Commission 2013j: 49). This is indeed at quite some remove from the above-mentioned initial ambitions for the Annual Convention, which included the annual review of the implementation of EPAP activities (see

11. In the view of the European Commission, 'The 2014 European Semester is the first to have been informed from its start by the guidance in the Social Investment Package, including notably the social objectives reflected in the Annual Growth Survey 2014 [...]' (European Commission 2013g: 2). Member states are requested 'to reflect in their National Reform Programmes the guidance provided in the SIP', while the Commission will 'address social protection reforms and the increased focus on social investment and active inclusion in Country Specific Recommendations and subsequent European Semesters' (European Commission 2013a: 22).

12. The SIP roadmap does not explicitly foresee specific procedures for exchanges with stakeholders at the EU level. Dialogue with stakeholders about the SIP has mainly taken place in EPAP's Annual Conventions and stakeholder dialogue meetings. 
section 2.2 above). The plenary discussions of the Annual Conventions in 2012 and 2013 have indeed been largely dominated by discussions about the SIP, while other topics (such as working poor) have been dealt with in workshops and 'side events' organised by stakeholders ${ }^{13}$.

\subsection{The EPAP Stakeholder dialogue: wider but increasingly shallow}

The objective of involving a broad range of stakeholders in the policy-making process is a longstanding feature of EU interventions in the area of social protection and (especially) social inclusion policies. It is reflected in the 'overarching objectives' of the Social OMC endorsed by the European Council in March 2006 (Council of the EU 2006a; 2006b) and has been reaffirmed by the Council of the European Union in 2011 (Council of the EU 2011b). Such an approach seems justified for several reasons (Frazer 2014a):

- stakeholders' involvement can contribute to the enhancement of the quality of policy-making, enriching the debate with knowledge, ideas and experience of people operating 'on the ground';

- it reinforces the democratic nature of the process and increases the legitimacy of decisions taken;

- stakeholders can raise awareness of EU initiatives, thus contributing to building up support.

Consequently, the third dimension to be considered when assessing the effectiveness of the EPAP is its capacity to effectively promote stakeholder involvement at both the EU and national level. Again, it would seem that while the actual operation of the Platform provided opportunities, it is beset also with some important shortcomings.

In the context of the EPAP, so-called 'Stakeholder dialogue meetings' have been organised since 2011: these meetings take place three times a year and provide the opportunity to develop a more structured dialogue (if compared to the previous period). Especially during the first years, this Stakeholder dialogue reached out to a wide range of stakeholders involved in the process, including social partners (both ETUC and BusinessEurope), international organisations (such as the ILO, UNICEF, the Council of Europe and the World Bank), EU institutions (the European Economic and Social Committee, the Committee of the Regions and, occasionally, the European Parliament) and Agencies (e.g. EUROFOUND and the Fundamental Rights Agency). The meetings between 2011 and 2014 were attended by up to 100 persons. Note that member state representatives rarely ever participate. In the initial years, member states' social attachés were regularly invited, but their interest in the stakeholder dialogue meetings was very low; representatives of the Presidency of the Council of the EU do occasionally attend.

13. It is to be noted that the 2013 Annual Convention of the European Platform Against Poverty and Social Exclusion has been included in the list of initiatives of the SIP (cf. European Commission 2014e: 5). 
In sum, the EPAP has promoted the interaction with a broader range of stakeholders which offers an opportunity to overcome one of the main limitations of the Social OMC, namely, the difficulty to reach out to actors and institutions that are outside the EU's 'inner circle' of Social Affairs actors ${ }^{14}$.

There is, however, a crucial flipside to this coin: the involvement of new stakeholders with a 'high-profile', technical expertise in the Stakeholder dialogue meetings has entailed a watering down of the role of the more traditional stakeholders such as EU civil society organisations, and decreased the attention paid to the involvement of people experiencing poverty. Even more importantly, the 'broadening' of the dialogue seems to have happened at the expense of the quality of the exchange, with the European Commission determining the agenda of the meetings and little time devoted to stakeholders' interventions. These meetings are especially instrumental for DG EMPL, which presents its priorities and actions, and gathers information about stakeholders' activities.

While information gathering and exchange of knowledge are essential, they represent only the first step for a significant engagement of stakeholders in the policy-making process (cf. Frazer 2014a). The potential of the stakeholder dialogue meetings to represent a forum for debating and reviewing policy developments and to create a shared understanding of priorities and key messages to be taken into account in key stages of the European Semester is barely exploited. As a result, the EPAP's stakeholder dialogue meetings seem to have been reduced to a largely bureaucratic exercise for exchanging information, which is again a far stretch from the 'shared commitment' which the EPAP was supposed to develop ${ }^{15}$.

This limited role for stakeholders is reflected also in the features of the Annual Conventions, the organisation of which is discussed during the Stakeholder dialogue meetings. The Annual Convention represents the Platform's most visible initiative, which results in considerable media attention ${ }^{16}$ that is enhanced by the presence of EU leaders and national Ministers ${ }^{17}$. However, the

14. Even if it is not possible to argue that this is a direct consequence of interactions during the stakeholder meetings, this collaboration may have spilled over into the Social Investment Package. Indeed, some of the SIP initiatives should be jointly undertaken with organisations such as the World Bank, the OECD, the United Nations Economic Commission for Europe, the World Health Organisation.

15. During the Stakeholder dialogue meeting on 24 January 2014 the European Commission launched the idea of abandoning the purely informative format and turning the Stakeholder Dialogue into a real dialogue. In this view, selected stakeholders could make contributions, present topics and lead the discussions (European Commission 2014d).

16. At least 40 media items regarding the 3 rd Annual Convention were published/broadcast. Over half of the coverage on the Convention came from the Spanish media (over 25\%) and Italian media (25\%) combined. Meanwhile, the EU media represented approximately $20 \%$ of the coverage. The rest of the coverage was fairly evenly divided (1-2 items) across the French, Portuguese, UK, Maltese, Croatian, Finnish, Hungarian, Austrian and international media. A steady trickle of coverage continued in the month after the Convention, continuing right up to 4 January 2014 - more than five weeks after the end of the Convention. Indeed, a quarter of the coverage is published on or after 1 December 2013 (Source: e-mail exchange with DG EMPL officials).

17. Besides the EU Commissioner for Employment, Social Affairs and Inclusion, the Presidents 
organisation of the Annual Convention is likely to limit stakeholders' ownership of the event as well as the ability to develop shared messages potentially affecting policy decisions. Indeed, the role of the European Commission in decisions about the Convention is predominant: while stakeholders have a clear role in managing 'side-events' and, in part, Convention workshops, they have a strictly limited role in defining the general focus and the specific themes of the Convention, even if they repeatedly voiced their wish, during the Stakeholder dialogue, to have a bigger say ${ }^{18}$. Finally, it is hard to see how recent substantial cuts ${ }^{19}$ in the financial resources of certain EU-level NGOs under the new Programme for Employment and Social Innovation 2014-2020 (EASI) will contribute to the EPAP's goal of enhancing stakeholder dialogue.

\subsection{Vertical integration}

Some of the initiatives foreseen by the EPAP are aimed at promoting a better vertical integration, namely between the EU and national levels of policymaking. Those initiatives mainly pertain to two areas for action: 1) making EU funding deliver on the social inclusion and social cohesion objectives of Europe 2020; and 2) promoting a partnership approach at the national level.

As regards funding, both Daly (2012: 279) and Armstrong (2012:284) noted that the quest for a better coordination of $\mathrm{EU}$ financial instruments to deliver on the social inclusion and social cohesion objectives represents a distinguishing feature of the EPAP. Indeed, the EPAP 'roadmap' contains some promising proposals, including:

- the use of part of the Structural and Cohesion Funds' resources (especially the ESF) for reaching the Europe 2020 anti-poverty target;

- finding better ways to finance social innovation;

- easing access to resources for stakeholders, small organisations and local groups (European Commission 2010a: 6-7) ${ }^{20}$.

of the European Council and of the European Commission attended the 2012 and 2013 Conventions, while the Vice-President of the European Parliament and the Commissioner for Health and Consumer policy attended the 2012 Convention and the EU Commissioner for the Internal Market and Services attended in 2013.

18. Concerns of this kind have also been expressed by the members of the Belgian Platform against Poverty and Social Exclusion in a letter addressed to the European Commission (SPP - Intégration Sociale 2013).

19. EAPN, FEANTSA and Eurocities' core grants have been reduced significantly. By contrast, CARITAS Europa saw its funding increased, while organisations are now also being funded (incl. SOLIDAR and EUROCARER).

2o. Indeed, the new rules of the European Structural and Investment (ESI) Funds for the period 2014-2020 take on board some of these proposals. The new regulation emphasises that spending must be concentrated on a small number of investment priorities linked to the objectives of the Europe 2020 Strategy and the National Reform Programmes. $23.4 \%$ of the cohesion policy resources is earmarked for the ESF, and at least 20\% of the ESF in each member state must be used for social inclusion (Vandenbroucke with Vanhercke 2014: 72). 
Those priorities were later recalled in the Social Investment Package, where the EC proposed to allocate at least $25 \%$ of cohesion policy funding to human capital and social investment through the $\mathrm{ESF}^{21}$; the Commission also convinced the member states to accept a minimum ring-fenced allocation of $20 \%$ of the total ESF resources of each member state to support for the fight against social exclusion and poverty (European Parliament and Council of the EU 2013a).

Importantly, ESF funding in this area will in the new programming period (2014-2020) be conditional upon the presence of 'A national strategic policy framework for poverty reduction, aiming at active inclusion' that 'provides a sufficient evidence base to develop policies for poverty reduction and monitor developments', 'contains measures supporting the achievement of the national poverty and social exclusion target (as defined in the National Reform Programme)' and 'involves relevant stakeholders in combating poverty' (EP and Council of the EU 2013b: 448). The non-respect of these new 'ex ante conditionalities' gives the Commission the power to ask for a revision of the member states' Operational Programme, or even to suspend interim payments under precisely defined conditions.

This renewed toolbox may be an important leverage with a view to better integrating $\mathrm{EU}$ and national policy-making processes, contributing, inter alia, to a greater involvement of stakeholders in the national policy-making arena. Indeed, at the national level, stakeholder involvement in the process of elaboration of relevant documents such as the NRPs is generally very limited (EAPN 2013b; Frazer 2014a; CoR 2014a), especially when compared to the Lisbon period (EAPN 2013b). The EPAP was clearly unable to address this problem. The elaboration of 'voluntary guidelines' for stakeholder involvement at the national level and the promotion of their implementation at national, regional and local level - one of the Platform actions planned for 2011/12 has been delayed until further notice (European Commission 2013f), mainly as a result of clear member state opposition to such guidelines, and it appears unlikely that guidelines will be elaborated in the short term (cf. Frazer 2014b: 27). The proposal has indeed been reiterated in the Social Investment Package but is not mentioned in the SIP roadmap. This said, the launch of the Europe 2020 strategy and the set-up of the EPAP have inspired structures for the engagement of stakeholders at the national level, such as the 'Belgian Platform against Poverty and Social Exclusion EU 2020', launched in 2011 and recently brought forward as a 'promising example' on the occasion of a PROGRESS peer review meeting (cf. Frazer 2014a, 2014b; Goris 2014) ${ }^{22}$.

21. The Commission commits to 'provide policy guidance on the use of ESI funds to support implementation of social investment' (European Commission 2013g: 6). In the framework of the SIP, the European Commission invites member states to 'involve stakeholders, particularly civil society organisations close to the target groups for social interventions, in programming and implementation and facilitate their access to funds' (European Commission 2013a: 18).

22. The Belgian Platform brings together a variety of stakeholders from all levels of governance and a broad mix of public and private organisations. The basic function of the Belgian Platform - which meets four times a year plus a bi-annual 'Open Platform Day' meeting - is the preparation and monitoring of European and Belgian policy against poverty and 
Summing up this section, the promotion of vertical integration represents a flaw in the Platform's operation: even if one of its areas of action is 'enhancing policy coordination among the member states', the EPAP lacks (even soft) instruments for directly influencing member state behaviour. Some exceptions apart, the EPAP is not systematically linked to 'National Platforms against poverty' or similar bodies that would allow to ensure the link with the regional and local level and the involvement of other national stakeholders (see EAPN 2010); nor is there a clear link with the work of the Social Protection Committee, as a result of the ambiguities about the division of labour between the EPAP and the Social OMC (see section 3.2). This evidently limits the EPAP's capacity to promote strong integration between the EU and domestic levels of governance. According to the CoR (2014a), this seems to be a common problem of all the Europe 2020 Flagship initiatives which should now be turned '[...] into an effective lever for policy coordination at all levels' (ibid: 53, emphasis in the original).

social exclusion (e.g. by contributing to the preparation and follow-up of the Belgian NRPs and NSRs). Even if both strengths and weaknesses of the specific Belgian example have emerged from the peer review (cf. Frazer 2014b), it can be said that the idea of creating national platforms appears quite promising insofar as they might contribute to bridging the gap between EU and domestic processes. Source: Peer review on 'The Belgian Platform against Poverty and Social Exclusion EU 2020', Brussels, 14-15 January 2014 (http:// ec.europa.eu/social/main.jsp?catId=1024\&langId=en\&newsId=1897\&furtherNews=yes). 


\section{The EPAP beyond the Mid-Term Review: three scenarios}

The analysis presented in section 3 provides a rather gloomy picture of the effectiveness of the European Platform against Poverty and Social Exclusion four years into its operation. As feared by Armstrong (2012: 287), the flagship failed to express a sufficiently ambitious and realizable social policy agenda. The limitations of the Platform have been clearly recognised by the European Commission. Thus, the Annex to the Communication on Taking stock of the Europe 2020 Strategy recognises that, on the one hand, the adoption of the SIP has to a large extent shifted the policy focus and communication efforts away from the EPAP and, on the other hand, the Platform 'did not fully succeed in creating a coherent and integrated framework for social policies and exploiting the synergies between the different actions' (European Commission 2014a: 35). The conclusion reached by the Commission is surprisingly straightforward: the EPAP 'is rather a collection of initiatives and the value added of the flagship initiative is not self-evident' (ibid.). For several of our interviewees, this is euro-speak that serves to pave the way for the Secretariat-General of the European Commission to dismantle the antipoverty flagship.

While our assessment above confirms that the EPAP is not living up to expectations (to put it mildly), discontinuing it would in our view lead to a further weakening of the social component of the Europe 2020 Strategy, while wasting the positive developments it has promoted. In our view, throwing out the baby with the bath water is not the way forward. Indeed the EU's commitment to stakeholder participation - including in the new Regulation of the European Structural and Investment Funds 2014-2020 - would mean that in any case a new structure for dialogue would need to be created. We would therefore suggest significantly enhancing the Platform, by clarifying and strengthening its role in the EU's social policy architecture, and creating synergies with the other existing processes.

In order to do this, three scenarios can be envisaged, each of them stressing one specific function that a renewed EPAP might perform. These scenarios are not mutually exclusive. On the contrary: they should be regarded as complementary stepping stones, each of which can raise the level of ambition of the EPAP. The three scenarios build on and further refine earlier proposals which aim to turn the EPAP into an important and complementary mechanism that adds value to the work of the Social OMC and the SIP. 


\section{Scenario 1 - A hub for discussing the social dimension of Europe $2020^{23}$}

A reformed EPAP should, as a first step, become a real hub for discussing the EU's social and anti-poverty initiatives, namely by:

a) Regularly debating the effectiveness and enhancement of the social dimension of Europe 2020 with a wide range of stakeholders, so as to create a sense of ownership;

b) Identifying and regularly updating priority actions of both the Social OMC and the SIP in the light of new developments;

c) Mapping the Europe 2020 initiatives with social implications undertaken by various actors and monitoring their implementation;

d) Proposing greater linkages between the patchwork of different components that make up Social EU and become the visible face of the social dimension of Europe 2020.

A precondition for the EPAP to become a real hub for discussing social and anti-poverty policy is that clearer and more structured links should be developed with the Social OMC on the one hand and the Social Investment Package on the other.

Given its iterative feature, fields of actions (social inclusion, healthcare and longterm care, and pensions), enhanced monitoring tools and links with national levels (e.g. through the NSRs), the Social OMC should represent the dynamic and coherent EU 'Social Agenda' from which the EPAP selectively picks up priorities and initiatives, and update them in the light of new social developments. Similarly, the EPAP could regularly involve stakeholders in discussing how the Social Investment strategy is being effectively implemented in member states, and how stronger linkages with mainstream EU initiatives - for example the NRPs and European Structural and Investment (ESI) Funds - can be developed. Such a closer link between the EPAP and the existing processes would ensure a regular 'updating' of the Social OMC and the SI Strategy with new priorities and initiatives.

In addition, the regular exchange with EU and national stakeholders would provide the existing processes with a reality check 'from the ground', including feedback about the implementation of these initiatives at the national level. Creating the 'ownership' of the flagship requires giving a greater role to the stakeholders, who have so far been left on the margins, in the functioning of the EPAP (e.g. agenda-setting). More structured arrangements would be needed to involve the SPC in the activities of the EPAP, e.g. by regularly inviting the SPC Chair to the meetings and regularly reporting on EPAP's activities to the SPC. Institutional actors such as the European Social Partners, the European Parliament, the Presidency of the Council of the EU, the Committee of the Regions and the European Economic and Social Committee should be involved already at the stage of the selection of the new EPAP initiatives, which could 
later be endorsed by the European Parliament with a view to increasing their political weight.

\section{Scenario 2 - A bridge with the European Semester}

Scenario 1 proposed above is likely to contribute to improving the coherence among the 'social' tools of the Europe 2020 Strategy and the quality of the involvement of relevant stakeholders. At the same time, it is very much an 'insider dialogue' (i.e. among Social Affairs actors): there is not a lot of scope for ensuring that social policy concerns 'spill over' (are taken into account) into other EU processes, more particularly the European Semester. An enhanced EPAP could be more explicitly used for that purpose: the second scenario is that the Platform could represent a bridge for channelling social and antipoverty priorities into the main vehicles of the European Semester.

Promising ideas in that direction have been proposed by Jonathan Zeitlin, including 24 :

- Better integrating the EPAP into the European Semester cycle by establishing clear mechanisms through which messages and priorities developed under the Platform (especially through stakeholders meetings) can feed into the elaboration of AGS, the thematic country reviews of NRPs, and CSRs. Furthermore, the EPAP could be used to follow-up, monitor, report, and review progress on the Europe 2020 Social dimension.

- Exploiting the EPAP Annual Convention as an occasion for stocktaking and reporting on the European Semester, identifying good practices, and debating the way forward (including the definition of priorities for the AGS) ${ }^{25}$;

- The creation of National Platforms, allowing a structured and open consultation process, supplying inputs for the elaboration of documents such as the National Reform Programmes and the National Social Reports, as well as for monitoring the implementation of those reports and of CSRs.

This scenario implies that, alongside the European Commission, relevant EU committees (such as the SPC, EMCO and Economic Policy Committee) should be fully engaged in the process. Genuine debating - together with the national actors who are involved in the process, including civil society and people experiencing poverty - should be combined with the potential for independent resolutions with key messages to be submitted to the Council of the EU. Indeed, this seems a promising way to mainstream social priorities into the European Semester process at both the EU and national levels.

24. These proposals were put forward and discussed during an ad hoc meeting of the Social Policy Working Group of the Social Platform held on 24 June 2013 and on the occasion of a seminar on 'The Future of Europe 2020' organized by the Committee of the Regions on 3 December 2013 (CoR 2014b).

25. In order to provide useful contributions, the timing of the EPAP Annual Convention and stakeholder dialogue meetings should better fit into the decision-making cycle of the European Semester. 


\section{Scenario 3 - Social Europe's 'watchdog'}

In a third scenario the EPAP would be given a key role in monitoring how other-than-social EU policies - including policies promoted through the European Semester, e.g. in the AGS and CSRs - contribute to achieving the EU's common social objectives. More concretely, the EPAP should monitor and promote the use of social impact assessments within the Commission's impact assessment process. It could contribute to building up knowledge in this field, disseminate this to countries and promote involvement of stakeholders in the process (Frazer et al. 2010: 39-40). In this process, the EPAP could have a role in ensuring the implementation of the Lisbon Treaty's Horizontal Social Clause (promoting the use of social impact assessments as a way of mainstreaming the EU social inclusion objectives across all policy areas). Here again, synergies between the various monitoring tools developed by both the European Commission and the SPC should be developed.

Such a 'Social Europe watchdog' scenario would be fully consistent with the mandate received by Marianne Thyssen, the new Commissioner for Employment, Social Affairs, Skills and Labour Mobility (Juncker, 2014). Ms. Thyssen has indeed been asked by President Juncker to immediately start working on the deepening of our Economic and Monetary Union, which 'also includes developing social impact assessments for any future conditional stability support programmes for Euro-area countries' (ibid: 4). Given the current critically important debate on the social dimension of EMU, the EPAP should play a key role in monitoring the extent to which the EU's social objectives are being taken into account in the implementation of EMU and in proposing specific remedies where they are not. 


\section{Conclusions}

This Working Paper has pointed out some positive effects of the EPAP: listing the Platform's key initiatives enabled provision of an overview of ongoing and new actions linked to the EU fight against poverty and social exclusion, contributed to the identification of priorities on which to concentrate efforts, and paved the way to better use of existing resources and instruments. The fact that some of the EPAP initiatives fall outside the competences of DG EMPL revamped the inter-service consultation between a host of Commission DGs. Furthermore, the Stakeholder dialogue has, especially in the early years, broadened the circle of stakeholders involved in EU-level consultations.

However, some fundamental limitations emerge from our assessment. The EPAP is a rather static tool in that many of the scheduled initiatives have been completed, and it is not clear whether and how new initiatives will be introduced. More fundamentally, the EPAP actions constitute a 'list', not a coherent social agenda. This is mainly due to the weak and ambiguous links between the Platform and other key instruments of the EU toolbox in the fight against poverty, such as the Social OMC and the Social Investment Package. The EPAP further complicated the 'Social EU' patchwork, rather than enhancing the linkages between its components. As a result, there is no 'feeding in' from the EPAP to the European Semester, be it at the EU level (preparation of Annual Growth Surveys, CSRs) or at that of the member states (elaboration of NRPs).

There is also the key issue of the decreasing quality of stakeholder involvement at the EU level: the wider involvement of actors has not been paralleled by an improvement in the quality of their involvement, especially when it comes to civil society organisations. This entails the risk that the EPAP is ultimately reduced to a bureaucratic process for the exchange of information, with decisions being taken elsewhere. Promoting involvement of stakeholders at the domestic level seems to be 'off limits' for the EPAP, as is the monitoring of the social dimension of Europe 2020 and the promotion of the use of social impact assessments. While the presence of Herman Van Rompuy and José Manuel Barroso gave considerable publicity to the recent Annual Conventions, the EPAP can hardly be seen as the 'visible face of social Europe'. The fact that the EPAP is rarely referred to in the academic literature and in relevant documents of the SPC is rather revealing in this sense. 
Rather than throwing out the baby with the bathwater, we have proposed three scenarios that should be regarded as stepping stones towards an ambitious European Platform Against Poverty and Social Exclusion. A reformed EPAP should, as a first step, become a real hub for discussing Europe 2020's EU social and anti-poverty initiatives. The second and more ambitious scenario is that the EPAP would be the bridge that channels social and anti-poverty priorities into the main vehicles of the European Semester. Finally, the EPAP could have a key role in monitoring how other-than-social EU policies including policies promoted through the European Semester - contribute to achieving the EU's common social objectives. These complementary scenarios will contribute to putting the Platform back on track, so that it can contribute to achieving the EU's social objectives.

The mid-term review of Europe 2020 scheduled for 2015 provides a formidable window of opportunity in this respect: with the poverty-reducing impact of the welfare state being increasingly constrained by austerity and $78 \%$ of Europeans being convinced that 'helping the poor and socially excluded and enabling them to play an active part in society' is an important initiative for overcoming the economic and financial crisis (European Commission 2013d), it is high time for the EU to revamp its toolkit in the fight against poverty. 


\section{References}

Agostini C., Sabato S. and Jessoula M. (2013) Europe 2020 and the fight against poverty: searching for coherence and effectiveness in multilevel policy arenas, Working Paper LPF n. 3/2013, Torino, Centro Einaudi. http://www.centroeinaudi.it/ images/abook_file/LPF_3_2013_WeL_Agostini-Sabato-Jessoula.pdf

Armstrong K. (2012) EU social policy and the governance architecture of Europe 2020, Transfer, 18 (3), 285-300.

Barcevicius E., Weishaupt T. and Zeitlin J. (2014) Assessing the open method of coordination: institutional design and national influence of EU social policy coordination, Basingstoke, Palgrave Macmillan.

Committee of the Regions (CoR) (2011) Opinion of the Committee of the Regions on 'The European platform against poverty and social exclusion', Official Journal of the European Union, C 166, 7 June 2011.

Committee of the Regions (CoR) (2014a) CoR mid-term assessment on Europe 2020: rethinking Europe's growth and jobs strategy, Brussels. https://portal.cor.europa. eu/europe2020/Documents/CoR\%20Europe\%202020\%20mid-term\%20 assessment\%20report.pdf

Committee of the Regions (CoR) (2014b) Seminar on the future of Europe 2020, 3 December 2013: Summary of the main comments/conclusions, Brussels, 14 January 2014. https://portal.cor.europa.eu/europe2020/SiteCollection Documents/Future\%20of\%20Europe\%202020\%20seminar_SUMMARY.pdf

Costamagna F. (2013) The European semester in action: strengthening economic policy coordination while weakening the social dimension?, LPF-WEL Working Paper No. 5, Torino, Centro Einaudi. http://papers.ssrn.com/sol3/papers.cfm?abstract_ id $=2367768$

Council of the European Union (2006a) Brussels European Council 23/24 March 2006. Presidency Conclusions, 7775/1/06 REV 1, Brussels.

Council of the European Union (2006b) Joint report on social protection and social inclusion, 7294/06, Brussels.

Council of the European Union (2011a) The European platform against poverty and social exclusion. Flagship initiative of the Europe 2020 strategy. Opinion of the Social Protection Committee, 6491/11, Brussels.

Council of the European Union (2011b) The future of the social open method of coordination (OMC) - Endorsement of the opinion of the Social Protection Committee, 10405/11, Brussels.

Council of the European Union (2011c) Work programme of the Social Protection Committee for 2011,6498/11, Brussels.

Council of the European Union (2013) European semester - roadmap on the implementation of the 2014 European semester, Doc. 16359/13, Brussels. 
Daly M. (2012) Paradigms in EU social policy: a critical account of Europe 2020, Transfer, 18 (3), 273-284.

Degryse C. (2012) The new European economic governance, Working Paper 2012.14. Brussels, European Trade Union Institute. http://www.etui.org/Publications2/ Working-Papers/The-new-European-economic-governance

Degryse C., Jepsen M. and Pochet P. (2013) The Euro crisis and its impact on national and European social policies, Working Paper 2013.05. Brussels, European Trade Union Institute. http://www.etui.org/Publications2/Working-Papers/The-Euro-crisisand-its-impact-on-national-and-European-social-policies

Derruine O. and Tiedemann A. (2011) The first European semester and its contribution to the EU2020 strategy. http://www.sven-giegold.de/wp-content/uploads/2011/10/ Europ.-Semester-contribution-to-EU2020.pdf

European Anti Poverty Network (EAPN) (2010) EAPN proposals on the European platform against poverty, Position paper, Brussels. http://www.eapn.eu/images/ stories/docs/EAPN-position-papers-and-reports/eapn-flagship-platform-againstpoverty-proposals-en.pdf

European Anti Poverty Network (EAPN) (2011a) EAPN first response to the European flagship platform against poverty and social exclusion: a European framework for social and territorial cohesion, Position paper, Brussels. http://www.eapn.eu/en/ news-and-publications/publications/eapn-position-papers-and-reports/eapn-firstresponse-to-the-european-flagship-platform-against-poverty

European Anti Poverty Network (EAPN) (2011b) EAPN input on the role of the social OMC in the context of Europe 2020, Position paper, Brussels. http://www.eapn.eu/ en/news-and-publications/publications/eapn-position-papers-and-reports/the-roleof-the-social-omc-in-the-context-of-europe-2020-eapns-input

European Anti Poverty Network (EAPN) (2012) An EU worth defending - beyond austerity to social investment and inclusive growth, EAPN analysis of the 2012 National Reform Programmes (NRPs) and National Social Reports (NSRs), Report, Brussels. http://www.eapn.eu/en/news-and-publications/publications/eapnposition-papers-and-reports/eapn-publishes-full-assessment-of-nrps-and-nsrs-an-euworth-defending-beyond-austerity-to-social-investment-and-inclusive-growth

European Anti Poverty Network (EAPN) (2013a) EAPN response to the Social Investment Package. Will it reduce poverty?, Position paper, Brussels. http://www.eapn.eu/ en/news-and-publications/publications/eapn-position-papers-and-reports/eapn-sresponse-to-the-social-investment-package-will-it-reduce-poverty

European Anti Poverty Network (EAPN) (2013b) Widening the gap. EAPN assessment of the National reform programmes 2013, Brussels. http://www.eapn.eu/en/newsand-publications/publications/eapn-position-papers-and-reports/eapn-publisheswidening-the-gap-2013-marked-the-3rd-round-of-national-reform-programmes-sincethe-launch-of-europe-2020-in-2010-eapn-has-engaged-in-this-process-every-year-

European Commission (2008) Communication from the Commission to the European Parliament, the Council, the European Economic and Social Committee and the Committee of the Regions. A renewed commitment to social Europe: reinforcing the open method of coordination for social protection and social inclusion, COM (2008) 418 final, 02 July 2008.

European Commission (2010a) Commission staff working paper. List of key initiatives. Accompanying document to the Communication from the Commission to the European Parliament, the Council, the European Economic and Social Committee and the Committee of the Regions. The European platform against poverty and social 
exclusion: a European framework for social and territorial cohesion, SEC (2010) 1564 final, 16 December 2010. http://eur-lex.europa.eu/LexUriServ/LexUriServ.do?uri= SEC:2010:1564:FIN:EN:PDF

European Commission (2010b) Communication from the Commission Europe 2020. A strategy for smart, sustainable and inclusive growth, COM (2010) 2020 final, 3 March 2010. http://eur-lex.europa.eu/LexUriServ/LexUriServ.do?uri=COM:2010:2 020:FIN:EN:PDF

European Commission (2010c) Communication from the Commission to the European Parliament, the Council, the European Economic and Social Committee and the Committee of the Regions. The European platform against poverty and social exclusion: A European framework for social and territorial cohesion, COM (2010) 758 final, 16 December 2010. http://eur-lex.europa.eu/LexUriServ/LexUriServ.do?uri= COM:2010:0758:FIN:EN:PDF

European Commission (2011) The social dimension of the Europe 2020 strategy A report from the Social Protection Committee (2011), Luxembourg, Publications Office of the European Union.

European Commission (2013a) Communication from the Commission to the European Parliament, the Council, the European Economic and Social Committee and the Committee of the Regions. Towards social investment for growth and cohesion including implementing the European Social Fund 2014-2020, COM (2013) 83 final, 20 February 2013.

European Commission (2013b) Communication from the Commission. Annual growth survey 2014, COM (2013) 800 final, 13 November 2013. http://ec.europa.eu/ europe2020/pdf/2014/ags2014_en.pdf

European Commission (2013c) Draft Minutes of the 6th meeting of the stakeholder dialogue of the European platform against poverty and social exclusion, 07 June 2013.

European Commission (2013d) Europe 2020 report, Standard Eurobarometer 79, Spring 2013, Brussels. http://ec.europa.eu/public_opinion/archives/eb/eb79/eb79_ eu20_en.pdf

European Commission (2013e) Platform actions completed as of July 16, 2013, DG Employment, Social Affairs and Inclusion. http://ec.europa.eu/social/main.jsp?catld $=961$ \&langld $=$ en $\&$ moreDocuments $=$ yes

European Commission (2013f) Platform actions ongoing as of July 16, 2013, DG Employment, Social Affairs and Inclusion. http://ec.europa.eu/social/main.jsp?catld $=961$ \&langld $=$ en\&moreDocuments $=y e s$

European Commission (2013g) Policy roadmap for the 2013-2014 implementation of the Social Investment Package, DG Employment, Social Affairs and Inclusion, November 2013 version.

European Commission (2013h) Proposal for a directive of the European Parliament and of the Council on the comparability of fees related to payment accounts, payment account switching and access to payment accounts with basic features, COM (2013) 266 final, 8 May 2013. http://eur-lex.europa.eu/LexUriServ/LexUriServ. do?uri=COM:2013:0266:FIN:EN:PDF

European Commission (2013i) Social Europe. Current challenges and the way forward, annual report of the Social Protection Committee (2012), Luxembourg, Publications Office of the European Union.

European Commission (2013j) Social policies - Social Europe guide - Volume 5, Luxembourg: Publications Office of the European Union. http://ec.europa.eu/social/ main.jsp?catld $=738 \&$ langld $=$ en\&publd $=7683 \&$ type $=2 \&$ furtherPubs $=$ yes 
European Commission (2013k), Draft joint employment report accompanying the Communication from the Commission on annual growth survey 2014, COM (2013) 801 final, 13 November 2013.

European Commission (2014a) Annexes to the Communication from the Commission to the European Parliament, the Council, the European Economic and Social Committee and the Committee of the Regions. Taking stock of the Europe 2020 strategy for smart, sustainable and inclusive growth, COM (2014) $130 \mathrm{final} / 2$, Annexes 1 to 3, 19 March 2014 (Corrigendum).

European Commission (2014b) Communication from the Commission to the European Parliament, the Council, the European Economic and Social Committee and the Committee of the Regions. Taking stock of the Europe 2020 strategy for smart, sustainable and inclusive growth, COM (2014) 130 final, 5 March 2014.

European Commission (2014c) Employment and social developments in Europe 2013 Luxembourg, Publications Office of the European Union. http://ec.europa.eu/social/ main.jsp?catld $=738 \&$ langld $=$ en $\&$ publd $=7684$

European Commission (2014d) Minutes of the 8th meeting of the stakeholder dialogue of the European platform against poverty and social exclusion, Brussels, 24 January 2014.

European Commission (2014e) Policy roadmap for the 2014 implementation of the Social Investment Package, February 2014 version, Brussels.

European Commission (2014f) Social Europe. Many ways, one objective. Annual report of the Social Protection Committee on the social situation in the European Union (2013), Luxembourg, Publications Office of the European Union.

European Economic and Social Committee (EESC) (2011) Opinion of the European Economic and Social Committee on the Communication from the Commission to the European Parliament, the Council, the European Economic and Social Committee and the Committee of the Regions on the European Platform against poverty and social exclusion: a European framework for social and territorial cohesion, COM (2010) 758 final, SOC/405, Brussels, 15 June 2011.

European Parliament (2014) New EU-procurement rules to ensure better quality and value for money, Press release, 15 January 2014. http://www.europarl.europa.eu/ pdfs/news/expert/infopress/20140110IPR32386/20140110IPR32386_en.pdf

European Parliament and Council of the EU (2013a) Regulation (EU) No 1304/2013 of the European Parliament and of the Council of 17 December 2013 on the European Social Fund and repealing Council Regulation (EC) No 1081/2006, Official Journal of the European Union, L 347, 20 December 2013.

European Parliament and Council of the EU (2013b) Regulation (EU) No 1303/2013 of the European Parliament and of the Council of 17 December 2013 laying down common provisions on the European Regional Development Fund, the European Social Fund, the Cohesion Fund, the European Agricultural Fund for Rural Development and the European Maritime and Fisheries Fund and laying down general provisions on the European Regional Development Fund, the European Social Fund, the Cohesion Fund and the European Maritime and Fisheries Fund and repealing Council Regulation (EC) No 1083/2006, Official Journal of the European Union, L 347, 20 December 2013.

Frazer H. (2014a) Involving stakeholders in developing policies to combat poverty and social exclusion, Discussion paper: Peer review on the Belgian platform against poverty and social exclusion EU 2020, Brussels, 14-15 January 2014.

Frazer H. (2014b) The Belgian platform against poverty and social exclusion EU 2020, Synthesis report, Luxembourg, Publications Office of the European Union. 
Frazer H., Marlier E., Natali D., Van Dam R. and Vanhercke B. (2010) Europe 2020. Towards a more social EU?, in Marlier E., Natali D. and Van Dam R. (eds.) Europe 2020: Towards a more social EU?, Brussels, P.I.E. Peter Lang, 15-44.

Frazer H., Guio A-C., Marlier E., Vanhercke B. and Ward T. (2014) Putting the fight against poverty and social exclusion at the heart of the EU agenda: A contribution to the mid-term review of the Europe 2020 strategy, Research paper no 15, Brussels, European Social Observatory. http://ose.be/EN/publications/ose_paper_series.htm

Goris J. (2014) The Belgian platform against poverty and social exclusion EU 2020, Host country paper Peer review on The Belgian Platform against Poverty and Social Exclusion EU 2020, Belgium 2014.

Jessoula M., Sabato S., Agostini C. and Madama I. (2014) The Europe 2020 Anti-poverty arena, Work Package 4 Multilevel "Arenas" for fighting poverty and social exclusion, Deliverable D 4.7, FP7 project 'Combating Poverty in Europe: Re-organising Active Inclusion through Participatory and Integrated Modes of Multilevel Governance'. http://cope-research.eu/wp-content/uploads/2014/10/COPE_Deliverable-4.7.pdf

Juncker J.-C. (2014) Mission letter to Marianne Thyssen, Commissioner Employment, Social Affairs, Skills and Labour Mobility, Brussels, 1 November 2014. http:// ec.europa.eu/about/juncker-commission/docs/thyssen_en.pdf

Lelie P. and Vanhercke B. (2013) Inside the social OMC's learning tools: how 'benchmarking social Europe' really works, Research Paper no. 10, Brussels, OSE. http://www.ose.be/files/publication/OSEPaperSeries/Lelie_Vanhercke_2013_ OseResearchPaper10.pdf

Marlier E., Natali D. and Van Dam R. (eds.) (2010) Europe 2020. Towards a more social EU?, Brussels, P.I.E. Peter Lang.

Peña-Casas R. (2012) Europe 2020 and the fight against poverty and social exclusion: fooled into marriage?, in Natali D. and Vanhercke B. (eds.) Social developments in the European Union 2011 , Brussels, OSE-ETUI, 159-185.

Piketty T. (2014) Capital in the twenty-first century, Cambridge, Mass., Harvard University Press.

Pochet P. (2010) EU 2020 - Social impact of the new form of European governance, Policy brief-European Social Policy, 5/2010, Brussels, European Trade Union Institute. http://www.etui.org/Publications2/Policy-Briefs/European-Social-Policy/ EU-2020-Social-impact-of-the-new-form-of-European-governance

Social Platform (2013) European platform against poverty and social exclusion and its Annual Convention, Letter to the Director "Europe 2020: Social Policies", DG Employment and Social Affairs, Brussels, July 12, 2013.

SPC (201 1a) Draft background paper to the SPC from the ad-hoc group on reinvigorating the social OMC in the context of the Europe 2020 strategy, SPC/2011.09/1.

SPC (201 1 b) The Social dimension of the Europe 2020 strategy - A report from the Social Protection Committee (2011), Manuscript completed in March 2011.

SPP-Intégration Sociale (2013) Organisation de la 3ème convention annuelle de la Plateforme européenne de lutte contre la pauvreté et l'exclusion sociale, Lettre de la Plateforme belge contre la pauvreté et l'exclusion sociale à la Commission européenne, 18. novembre 2013.

Vandenbroucke F. with Vanhercke B. (2014) A European Social Union. 10 tough nuts to crack. Backgroung report for the Friends of Europe Hight-level group on "Social Union", Brussels.

Vandenbroucke F., Diris R. and Verbist G. (2013) Excessive social imbalances and the performance of welfare states, Policy Paper, Leuven, Euroforum KU Leuven. https:// www.kuleuven.be/euroforum/viewpic.php?LAN=E\&TABLE=DOCS\&ID=855 
Vanhercke B. (2011) Is 'The Social dimension of Europe 2020' an oxymoron?, in Degryse C. and Natali D. (eds.) Social developments in the European Union 2010, Brussels, OSE and ETUI, 141-174. http://www.etui.org/Publications2/Books/Socialdevelopments-in-the-European-Union-2010

Vanhercke B. (2013) Under the radar? EU social policy in times of austerity, in Natali D. and Vanhercke B. (eds.) Social developments in the European Union 2012, Brussels, OSE and ETUI, 91-121. http://www.ose.be/files/bilan2012/Vanhercke_2013_Bil_ soc2012_EU_SocPOI_Austerity_EN.pdf

Zeitlin (2010) Towards a stronger OMC in a more social Europe 2020: a new governance architecture for EU policy coordination, in Marlier E., Natali D. and Van Dam R.

(eds.) Europe 2020: Towards a more social EU?, Brussels, PIE-Peter Lang, 253-273.

Zeitlin J. and Vanhercke B. (2014) Socializing the European Semester? Economic governance and social policy coordination in Europe 2020, Report prepared for the Swedish Institute of European Studies (SIEPS), forthcoming. 